\title{
LITHOLOGY, ROCK RELIEF AND KARSTIFICATION OF MINAMIDAITO ISLAND (JAPAN)
}

\section{LITOLOGIJA, SKALNI RELIEF IN ZAKRASEVANE OTOKA MINAMIDAITO (JAPONSKA)}

\author{
Martin KNEZ ${ }^{1,2}$, Tadej SLABE ${ }^{1,2}$, Kazuko URUSHIBARA-YOSHINO ${ }^{3}$
}

\begin{abstract}
UDC 552.54(520)

$551.435 .8(520)$

Martin Knez, Tadej Slabe \& Kazuko Urushibara-Yoshino: Lithology, Rock Relief and Karstification of Minamidaito Island (Japan)

Minamidaito Island is a karstified coral island located on the Philippine plate. Karstification periods occurred during the end of the Pliocene, in major part of the Pleistocene, and in the Holocene. The first period of karstification can be observed in the lower Daito dolomitized limestone (5 Ma and $4 \mathrm{Ma}$ ); the karstification seems to have occurred as a result of sea level change caused by the cooler conditions of the paleoclimatic environment. Geological studies were performed to study reef carbonates in detail. Among them, biointrasparite limestone of framestone and bafflestone types with transitions to grainstone and dolomitized biointrasparry limestone of framestone and bafflestone types dominate. Calcimetric analyses established that in certain locations the distribution of limestone and dolomite differs from the distribution previously described. Rock relief reveals the unique formation of coastal karren, the development of the surface in the interior of the island, and the most characteristic periods of cave development.

Key words: Minamidaito Island, lithlogy, coral dolomitized limestone, rock relief, coastal karren, karstification, vegetation.
\end{abstract}

Izvleček

UDK 552.54(520)

$551.435 .8(520)$

Martin Knez, Tadej Slabe \& Kazuko Urushibara-Yoshino: Litologija, skalni relief in zakrasevane otoka Minamidaito (Japonska)

Otok Minamidaito je zakrasel koralni otok na Filipinski plošči. Obdobja zakrasevanja so bila na koncu pliocena, skoraj ves pleistocen in v holocenu. Prvo obdobje zakrasevanja lahko razberemo v spodnjih Daito dolomitiziranih apnencih. Zakrasevanje je posledica spremebe gladine morja zaradi hladnješih paleoklimatskih razmer. $\mathrm{Z}$ geološkimi raziskavami smo podrobno preučili grebenske karbonate. Prevladujejo biointra sparitni apnenci tipa framestone in bafflestone s prehodi v grainstone ter dolomitizirani biointra sparitni apnenci tipa framestone in bafflestone. S pomočjo kalcimetričnih analiz smo ugotovili, da je razporeditev apnencev in dolomitov na nekaterih lokacijah drugačna od do sedaj opisane. Skalni relief razkriva svojevrstno oblikovanje obmorskih škrapelj, razvoj površja v notranjosti otoka in najbolj značilna obdobja razvoja jam.

Ključne besede: otok Minamidaito, litologija, koralni dolomitizirani apnenec, skalni relief, morske škraplje, zakrasevanje, vegetacija.

\section{INTRODUCTION}

Studies of the karst characteristics of Minamidaito Island were undertaken in the framework of a grant-in-aid project for the Scientific Research Program of the Ministry of Education, Science, Sports, and Culture of Ja-

\footnotetext{
${ }^{1}$ Karst Research Institute, Research Centre of the Slovenian Academy of Sciences and Arts, Titov trg 2, SI-6230 Postojna, Slovenia and UNESCO Chair on Karst Education, University of Nova Gorica, Glavni trg 8, SI-5271Vipava, Slovenia, e-mails: knez@zrc-sazu.si, slabe@zrc-sazu.si

${ }^{2}$ Yunnan International Karst Environmental Laboratory, Xueyun rd. 5, CN-650223, Kunming, China, e-mails: knez@zrc-sazu.si, slabe@zrc-sazu.si

${ }^{3}$ Nagayama Matsumori 28-9, Shizukuishi, Iwate Pref., Japan, 020-0585, e-mail: kazukouy@mocha.ocn.ne.jp

Received/Prejeto: 09.06.2015
} 
pan and the Karst Research Program (Slovene Research Agency) of Slovenia. Part of the project was devoted to broadening knowledge about the development of the island's karst (preliminary information was prepared for the local conference, Knez et al. 2013), augmented with a study of lithomorphogenesis, part of the global study of the formation of karst surfaces given diverse rock, conditions, and different regional frameworks (Knez \& Slabe 2002; Debevec et al. 2012; Al Farraj Al Ketbi et al. 2014; Gutiérrez Domech et al. 2015; Knez et al. 2011, 2012, 2015; Slabe 2005, 2009; Slabe et al. 2016; and, Karst Rock Features book (Ginés et al. 2009). A variety of characteristics of the formation and development of karst features is clearly evident.

Minamidaito Island is located on the Philippine plate. The island has been karstified since the Pleistocene (Suzuki et al. 2006). The present study of Minamidaito Island examines the karstification periods during which the layers developed into their present state and provides measured solution values of the limestone tablets studied. Dating data on dolomitized limestone obtained by previous studies is used to estimate the age of karstification.

Numerous studies have been done on the formation of Minamidaito Island and even more studies have dealt with the Kitadaito atoll located $12 \mathrm{~km}$ away (cf. Suzuki et al. 2006). Their proximity explains a number of parallel characteristics and the same or very similar development and processes. The studies included coral limestone and dolomitized limestone and calcimetric analyses. Rock from Kaigunbo and several other locations on the island was described in detail.

The composition of the coral rock significantly influences the formation of the rock relief of karst features on the surface and in the caves on the island. Coral rock is mostly composed of larger whole or fragmented coral with fragile connections. This not only affects the surface of the rock and its relief but also its shape. The traces of rock formation by the factors characteristic of the environment are clearly visible.

The rock relief of karst phenomena, which develops uniquely given diverse rock and conditions, is often an indicative trace of the manner of their formation and development. Detailed mapping (type, position, shape, size) and studies of the origin of surface and cave rock forms increased our knowledge about their formation and the factors and processes decisive for the development of karst on Minamidaito.

\section{GEOMORPHOLOGICAL SKETCH OF THE STUDY AREA}

Minamidaito Island is located on the Philippine plate. The island lies about $360 \mathrm{~km}$ southeast of Okinawa Island. This island is shifting toward the Ryukyu subduction zone at a speed of about 4 to $5 \mathrm{~cm} /$ year. Shown in
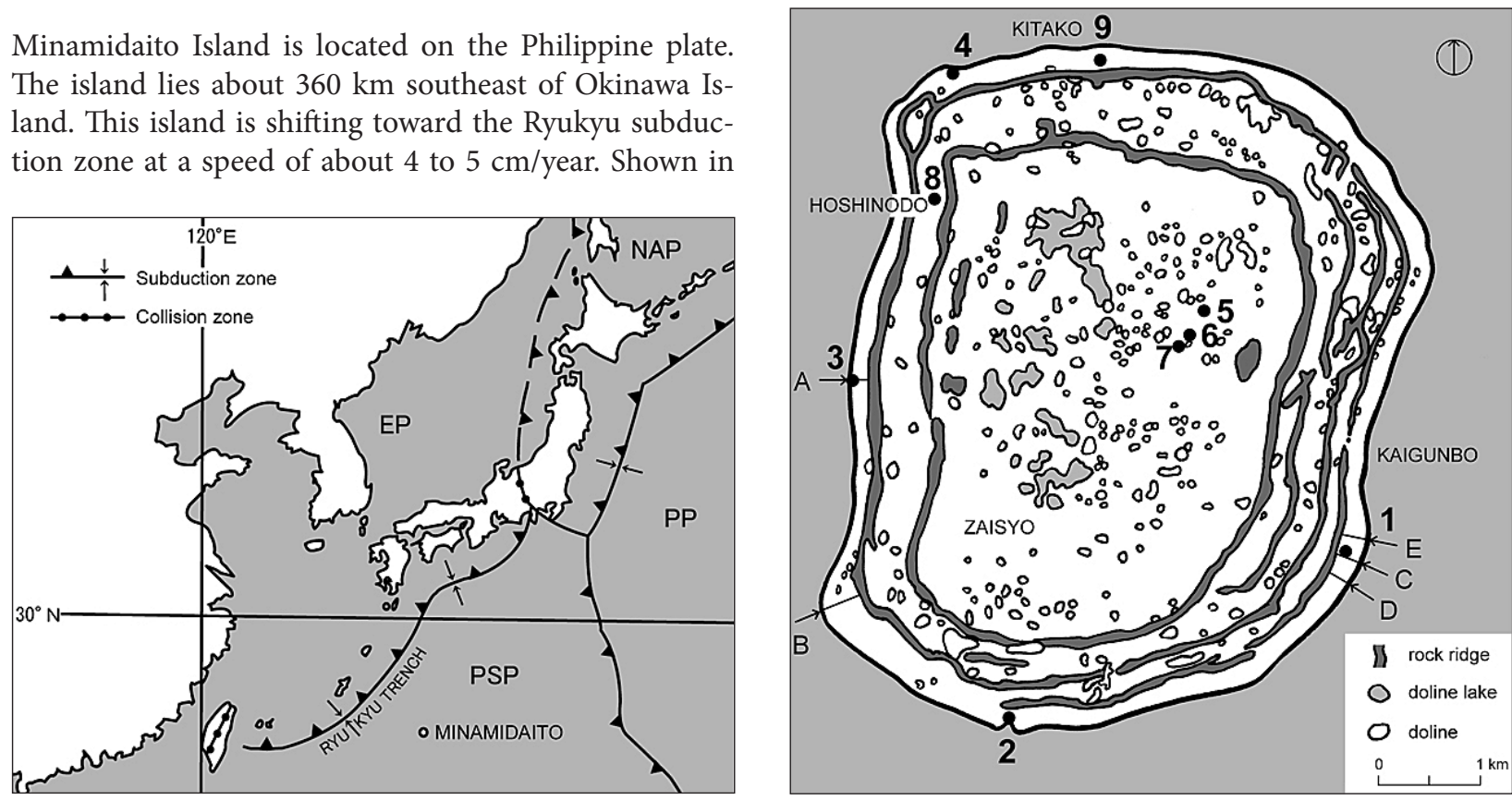

Fig. 1: Location of Minamidaito Island and map of the island with research points: 1-profile at Kaigunbo, 2- South port, 3- West port, 4- North port, 5-Cave Point No. 7, 6- Oshiro 1 Cave, 7- Oshiro 2 Cave, 8-Hoshinodo Cave, 9-crevice; A to E- profiles from see level to the tops of the ridge (see Fig. 4). 


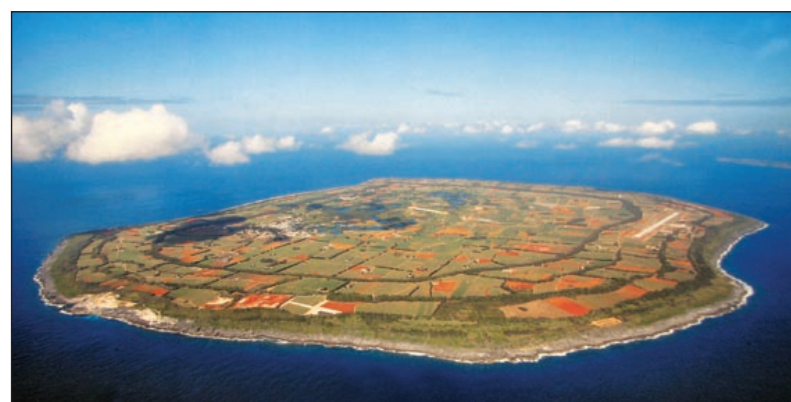

tivate sugar cane. Topographically, the outer ring of the higher parts with limestone walls has an average elevation of 40 to 50 meters a.s.l. The highest part is 75 meters a.s.l. The lower part of the ring has a basin-like form with doline lakes. The average elevation is about 8 meters a.s.l. The water table of the doline lakes is 2 meters a.s.l. The karst terrain of the island is shown in Fig. 3 (UrushibaraYoshino et al. 2017).

The caves in the higher land areas developed verti-

Fig. 2B: Aerial view of the island (Photo: NPO Dongosabows).

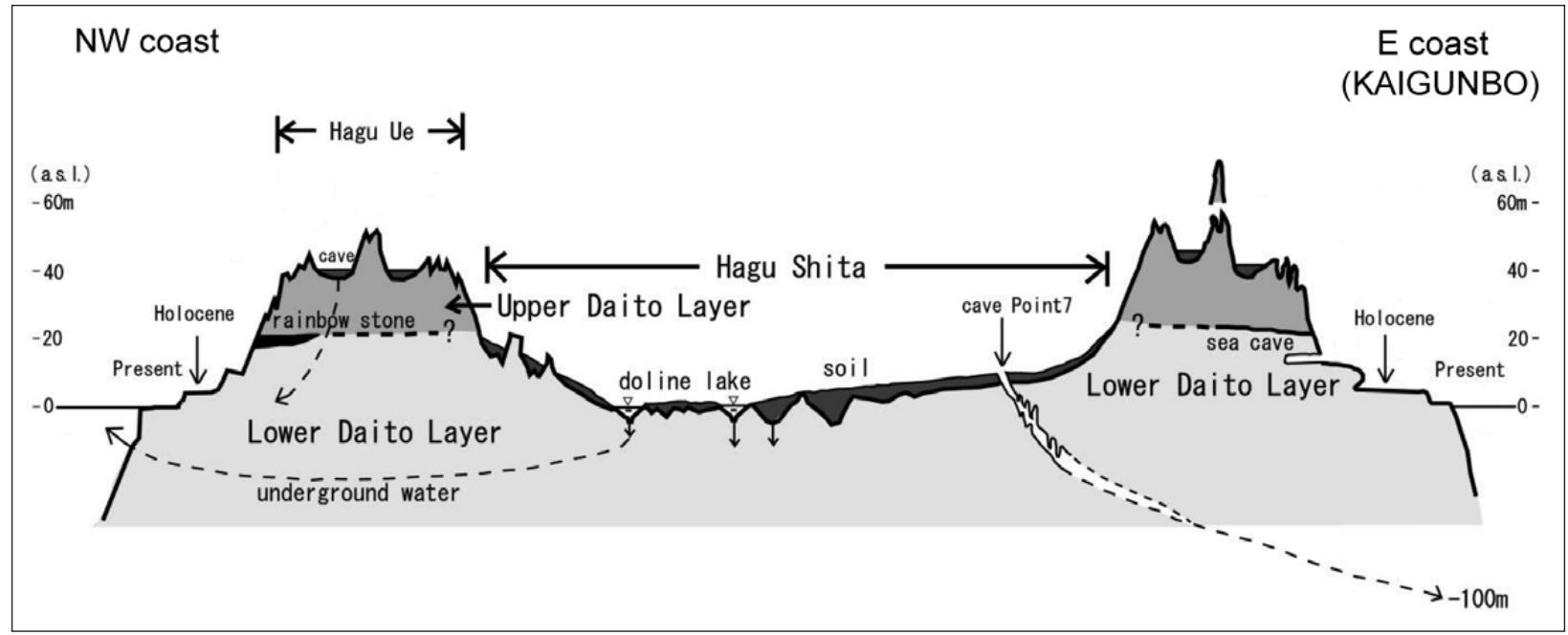

Fig. 3: Cross-section of the island.

Figs. 1 and 2, the location of the island is $25^{\circ} 50^{\prime} 47^{\prime \prime} \mathrm{N}$ and $131^{\circ} 14^{\prime} 24^{\prime \prime} \mathrm{E}$. Its north-south axis stretches $6.54 \mathrm{~km}$, and its east-west axis, $5.78 \mathrm{~km}$. The island was named Borodino Island in 1820 by the Russians.

In 1885, a baseline post named Kaigunbo was established on the east coast for a survey. The population of the island was 1,447 in 2010 . The people mainly cul- cally with many speleothems. Caves are also found in the lowlands. The speleothems are distributed below the water table, indicating that the caves were formed during a lower sea level period under a cold climate. However, the speleothems in the Point 7 cave (Figs. 1, 3) were formed under the condition of a higher sea level during the Holocene.

\section{PREVIOUS STUDIES}

The bedrock layers of Kitadaito Island, located $12 \mathrm{~km}$ northeast of Minamidaito Island, have been thoroughly studied by geologists. According to their findings, it was possible to approximate data for the bedrock layers of Minamidaito Island. Between 1934 and 1936, borehole studies to a depth of -431.6 meters were made on Kitadaito Island (Sugiyama 1934, 1936; Hanzawa 1940). These studies reported pure limestone accumulation since the early Miocene. The upper parts (ca. $100 \mathrm{~m}$ ) of the accumulation layer contain dolomitized limestone. The age of the layer was reported as Pliocene to Pleistocene. The geology was explained as follows: "Kitadaito and Minamidaito islands moved from the equatorial region to the present region, and these islands arrived at an uplifting zone as they neared the subduction zone about $1 \mathrm{Ma}$ " (Hanzawa 1940). Ohde and Kitano (1982) and Ohde (1987) attempted to explain the dolomite of the Pleistocene layer, concluding that it is proto-dolomite formed in the lagoonal area of the atoll. 
Using uranium-series dating, neotechtonic studies subsequently succeeded in dating the coral (Ota et al. 1991; Toshio et al. 1991; Omura \& Ota 1992). They came to the conclusion that the dated coral area was located at about 12 meters a.s.l. The uplift rate of Minamidaito is less than $0.05 \mathrm{~m} / \mathrm{ka}$. Around the same time, Ohde and Elderfield (1992) undertook the dating of the dolomitization through a borehole on Minamidaito Island. They obtained Daito dolomite at $0-10$ meters a.s.l. that was dated at $5 \mathrm{Ma}$. The dolomite at 10-64 meters a.s.l. was dated at 2 Ma. Reexamining the samples obtained by Sugiyama in 1934 and 1936, other researchers reported that the ages of the dolomite on Kitadaito could be classified into several layers in detail (Inagaki \& Iryu 1998;
Nambu et al. 2003; Suzuki et al. 2006; Hideo et al. 2010). Their conclusions can be summarized as follows: (1) Minamidaito is not an uplifted atoll, (2) the present terrain is a result of karstification, and (3) the upper part of the bedrock above -100 meters was dolomitized on Kitadaito Island.

Part of coral limestone was dolomitized in seawater (Nambu et al. 2003). There is a surface of unconformity between older and younger dolomite beds. The older is about $4.9 \mathrm{Ma}$ while that younger is about $2.1 \mathrm{Ma}$ old (Nambu et al. 2003). Suzuki et al. (2006) reported that dolomite is also in the upper part (dated from 5.5 to $1.6 \mathrm{Ma})$.

\section{GEOLOGICAL STUDIES}

\section{PROFILES}

Rock samples were taken in selected beds from sea level to the top of the ridge in a southeast-northwest direction. Twenty-three samples of the rock were taken from the profile and examined microscopically. From 23 rock samples, 17 microscopic thin sections were prepared and examined in transmitted light. Prior to the microscopic examination, half of each thin section was dyed in alizarin red dye (1.2-dihydroxyanthraquinone, known also as Mordant Red 11, Evamy and Sherman 1962). Combining the observations with the results of the complexometric titration analysis, we were able to determine the properties of the rock. The rocks were classified according to Folk's $(1959,1962)$ petrographic classification of limestones and Dunham's (1962) classification of carbonate rocks supplemented by Embry and Klovan (1972). Using the dissolving method (Engelhardt et al. 1964) we performed 26 complexometric titration analyses on 23 rock samples (Tab. 1, samples from 1 to 23).

\section{KAIGUNBO}

The profile on the eastern coast of the island was studied in detail (Figs. 1 (point 1), 4C, 5). The geological description covers the distance from the water table to the top of the ridge in a southeast-northwest direction. The rock is moderately to thickly layered with layers between 10 centimeters and several meters thick. The dip of the beds changes along the profile, primarily running toward the northwest and ranging between $5^{\circ}$ in $20^{\circ}$. Macroscopically, the upper planes of the beds in the lower section of the profile and in the cross sections contain numerous smaller and larger remnants of coral. The largest examples are several tens of centimeters in diameter. The rock is covered by a microbic biofilm that accounts for the almost entirely grey surface of the rock. The only exceptions are individual areas where stronger waves reach higher on a 70-meter long shelf inclined at a $10^{\circ}$ average whose highest part is about ten meters above the level of the sea. These areas reveal the true white colour of the rock because the frequent movement of the numerous pebbles and boulders (some up to several cubic meters in size) polishes the surface. Primary porosity is observed everywhere. Rock fissuring is not distinctive but predominantly subvertical faults and fissures in all directions can be traced. The thickness of the studied profile totals 40 meters. The age of the rock ranks it in the Daito formation (UrushibaraYoshino 2003).

The description of the profile was divided into two areas. The first area occupies the almost 70-meter wide limestone rock shelf where the rock is periodically in contact with seawater. The lower section of the shelf lies between high and low tides (Samples 1 to 5, Fig. 5, Tab. 1) while the slightly inclined and roughly 50-meter long upper limestone section (Fig. 6a) is only reached by high waters during typhoons and severe storms a few times a year (Samples 6 to 10). The second area (Samples 11 to 23 ) is the almost vertical dolomitized (Fig. 6b) cliff above the level shelf that is affected by the more or less constant spray of seawater.

Fourteen rock samples were taken at different locations on the island (South Port, West Port, North Port, and in three caves: Oshiro 1 and Oshiro 2 caves and Hoshinodo Cave). 26 complexometric titration analyses were done on them (Tab. 1, samples 24 to 35 and 37). 26 more complexometric titration analyses 
LITHOLOGY, ROCK RELIEF AND KARSTIFICATION OF MINAMIDAITO ISLAND (JAPAN)

\begin{tabular}{|c|c|c|c|c|c|c|c|}
\hline $\begin{array}{l}\text { Rock } \\
\text { sample }\end{array}$ & $\begin{array}{c}\mathrm{CaO} \\
(\%)\end{array}$ & $\begin{array}{c}\mathrm{MgO} \\
(\%)\end{array}$ & $\begin{array}{c}\text { Dolomite } \\
(\%)\end{array}$ & $\begin{array}{c}\text { Total } \\
\text { carbonate } \\
(\%)\end{array}$ & $\begin{array}{c}\text { Calcite } \\
(\%)\end{array}$ & $\begin{array}{l}\mathrm{CaO} / \\
\mathrm{MgO}\end{array}$ & $\begin{array}{c}\text { Insoluble } \\
\text { residue } \\
(\%)\end{array}$ \\
\hline 1 & 52.49 & 1.37 & 6.27 & 99.20 & 92.93 & 38.31 & 0.80 \\
\hline 2 & 54.11 & 0.44 & 2.28 & 97.49 & 95.21 & 122.98 & 2.51 \\
\hline 3 & 51.78 & 1.63 & 7.47 & 95.83 & 88.36 & 31.77 & 4.17 \\
\hline 4 & 51.87 & 1.29 & 5.90 & 95.28 & 89.38 & 40.21 & 4.72 \\
\hline $5 a$ & 53.98 & 0.44 & 1.84 & 97.10 & 95.26 & 122.48 & 2.90 \\
\hline $5 b$ & 53.72 & 0.81 & 3.69 & 97.57 & 93.88 & 66.32 & 2.43 \\
\hline 6 & 54.23 & 0.68 & 3.13 & 98.21 & 95.08 & 79.75 & 1.79 \\
\hline 7 & 53.61 & 0.16 & 0.74 & 96.01 & 95.27 & 335.06 & 3.99 \\
\hline 8 & 41.89 & 10.52 & 48.13 & 96.76 & 48.63 & 3.98 & 3.24 \\
\hline 9 & 54.34 & 0.56 & 2.58 & 98.17 & 95.59 & 97.03 & 1.83 \\
\hline 10 & 46.55 & 7.38 & 9.22 & 98.51 & 89.29 & 6.30 & 1.49 \\
\hline 11 & 36.84 & 16.20 & 74.14 & 100 & 25.86 & 2.27 & 0.0 \\
\hline $12 a$ & 38.30 & 19.23 & 87.97 & 97.86 & 9.89 & 1.99 & 2.14 \\
\hline $12 b$ & 32.36 & 19.43 & 88.89 & 98.39 & 9.50 & 1.67 & 1.61 \\
\hline 13 & 34.43 & 15.20 & 69.67 & 93.24 & 23.57 & 2.27 & 6.76 \\
\hline 14 & 31.12 & 17.21 & 75.24 & 91.53 & 16.29 & 1.81 & 8.47 \\
\hline 15 & 56.47 & 0.12 & 0.55 & 100 & 99.45 & 4.70 & 0.00 \\
\hline 16 & 33.82 & 16.53 & 75.61 & 94.93 & 19.32 & 2.05 & 5.07 \\
\hline $17 a$ & 33.59 & 17.90 & 81.70 & 97.38 & 15.58 & 1.88 & 2.62 \\
\hline $17 b$ & 33.93 & 16.13 & 74.32 & 94.58 & 20.26 & 2.10 & 5.42 \\
\hline 18 & 36.39 & 10.68 & 48.87 & 86.79 & 37.92 & 3.41 & 13.21 \\
\hline 19 & 33.59 & 15.52 & 75.61 & 92.01 & 16.40 & 21.64 & 7.99 \\
\hline 20 & 36.06 & 15.68 & 71.74 & 97.15 & 25.41 & 2.30 & 2.85 \\
\hline 21 & 39.82 & 13.26 & 60.67 & 98.80 & 38.13 & 3.00 & 1.20 \\
\hline 22 & 33.31 & 17.38 & 79.48 & 95.80 & 16.32 & 1.92 & 4.20 \\
\hline 23 & 33.20 & 18.86 & 86.31 & 98.57 & 12.26 & 1.76 & 1.43 \\
\hline 24 & 38.58 & 14.43 & 66.02 & 98.04 & 32.02 & 2.67 & 1.96 \\
\hline 25 & 42.75 & 10.64 & 48.69 & 98.51 & 49.82 & 4.02 & 1.49 \\
\hline 26 & 33.26 & 16.65 & 76.16 & 94.18 & 18.02 & 2.00 & 5.82 \\
\hline 27 & 46.88 & 7.46 & 33.93 & 99.27 & 65.34 & 6.28 & 0.73 \\
\hline $27 a$ & 47.50 & 5.52 & 25.26 & 96.21 & 71.05 & 8.60 & 3.69 \\
\hline 28 & 50.36 & 3.43 & 15.67 & 97.05 & 81.38 & 14.68 & 2.95 \\
\hline 29 & 35.44 & 16.73 & 76.35 & 98.24 & 21.89 & 2.12 & 1.76 \\
\hline 30 & 52.88 & 0.50 & 9.22 & 95.33 & 89.38 & 86.11 & 1.40 \\
\hline 31 & 53.16 & 1.97 & 9.04 & 99.00 & 89.96 & 26.98 & 1.00 \\
\hline 32 & 54.95 & 0.68 & 3.13 & 99.49 & 96.36 & 80.80 & 0.51 \\
\hline 33 & 32.58 & 19.27 & 88.15 & 98.45 & 10.30 & 1.69 & 1.55 \\
\hline 34 & 33.09 & 19.07 & 87.23 & 98.94 & 10.31 & 1.74 & 1.06 \\
\hline 35 & 33.14 & 16.25 & 74.32 & 93.11 & 18.79 & 2.04 & 6.89 \\
\hline 36 & 52.49 & 1.69 & 17.75 & 97.21 & 89.46 & 31.06 & 2.79 \\
\hline 37 & 32.30 & 19.07 & 87.23 & 97.52 & 10.29 & 1.69 & 2.48 \\
\hline 38 & 54.40 & 0.77 & 3.50 & 98.70 & 95.20 & 70.65 & 1.30 \\
\hline 39 & 53.33 & 1.45 & 6.64 & 98.21 & 91.57 & 36.77 & 1.79 \\
\hline 40 & 27.09 & 1.13 & 5.16 & 50.71 & 45.55 & 23.97 & 49.29 \\
\hline 41 & 53.50 & 1.65 & 7.56 & 97.10 & 89.54 & 32.42 & 2.90 \\
\hline
\end{tabular}

Tab.1: Complexometric analysis of rock samples. 


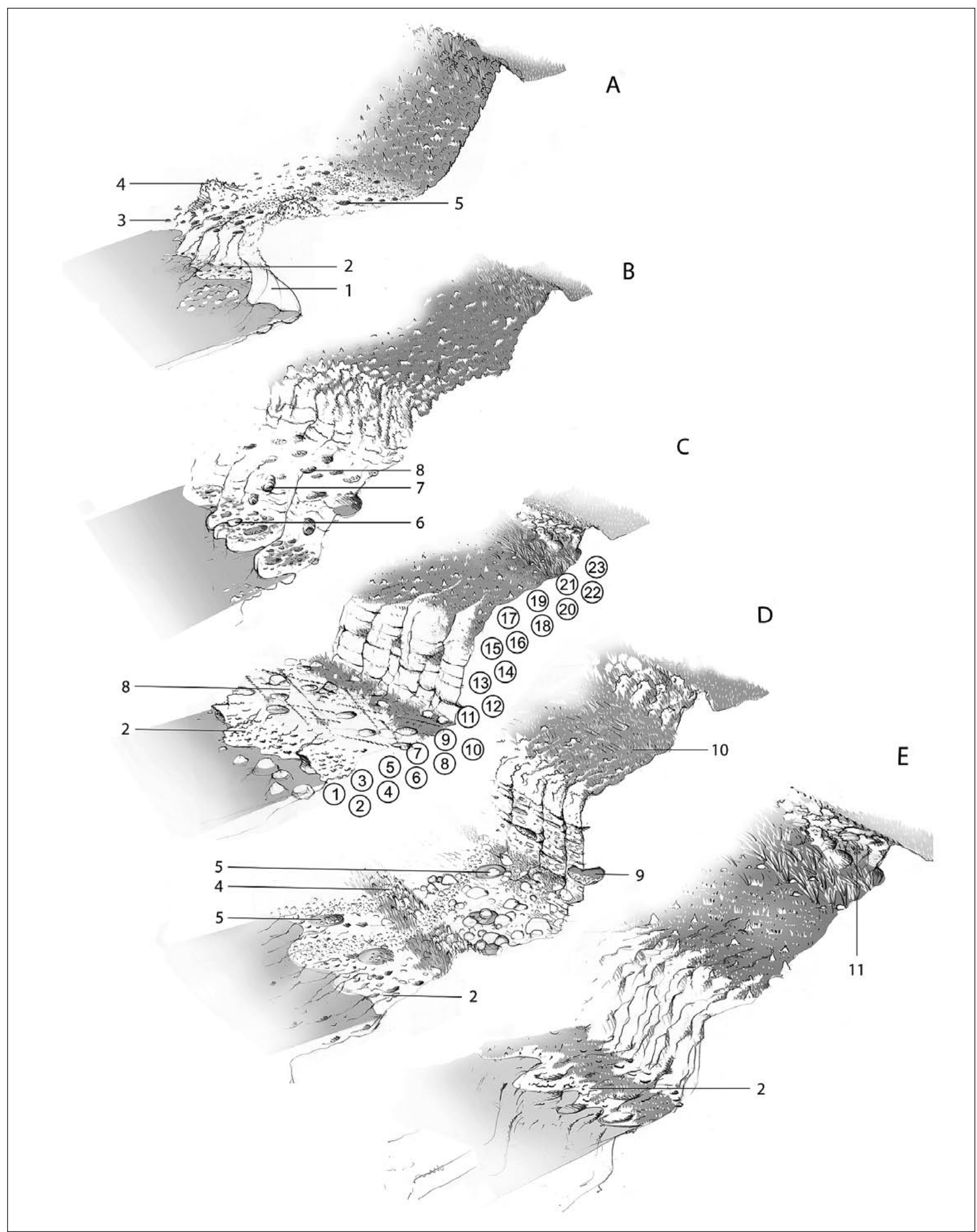

Fig. 4: Profiles from see level to the tops of the ridge with rock relief: 1- sea notch, 2-small sea pans, 3-large sea pans in a row, 4-surface etched by sea spray, 5- large pans formed by corrosion and erosion, 6-complex of sea pans, 7-opened sea pan on the wall, 8- sea pans formed by sea spray, 9- erosional cave, 10- subsoil surface, 11- by sea spray and rain etched and partly disintegrated rocky ridge. Circled numbers from 1 to 23: sites of rock samples with matching numbers. 


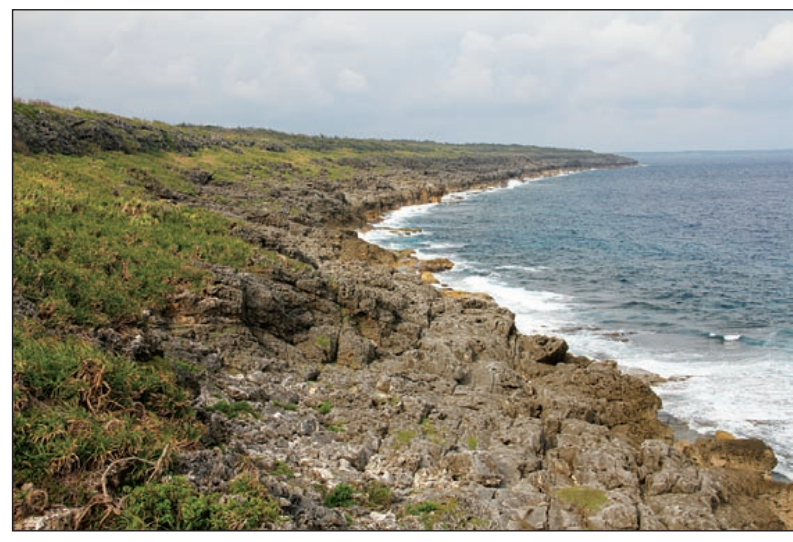

Fig. 5: Kaigunbo bay on the eastern coast (see Fig. 1).

were done on five dripstone samples (Tab. 1, samples 36 and 38 to 41 ).

\section{Limestone shore platform}

At the beginning of the profile, the rock is biointramicrosparite to biointrasparite limestone (grainstone to boundstone and bafflestone to framestone). Calcite minerals dominate, and only occasionally do we find dolomite clasts fringing the fenestrae inside the sample limestone. Euhedral to subhedral dolomite crystals of one generation do not exceed $45 \mu \mathrm{m}$ and only occasionally fringe the interior edge of fenestrae. Dolomite crystals comprise around $5 \%$, insoluble residues a few percent (mostly between $1 \%$ and $4 \%$ ), and the rest is calcite. The samples contain numerous whole corals and coral fragments but these do not exceed $10 \%$ of the total mass. Well sorted micrite and microsparite intraclasts dominate, usually between 0.14 and $0.45 \mathrm{~mm}$ in diameter. Among the orthochems, calcite drusy mosaic cement with grains that do not exceed $45 \mu \mathrm{m}$ dominates. Porosity is primarily intragranular to fenestral and partly framework porosity and estimated at $5 \%$ to $10 \%$. Secondary porosity is not observed, and there are no calcite veins.

In the continuation of the profile in the higher and younger beds, the rock does not change significantly. The dolomite content remains constant and amounts to about $3 \%$ (Sample 3). The samples contain numerous plankton and other foraminifera and fragments of gastropods and bivalves. The edges of fenestrae clearly show the acicular radial fibrous type of dolomite crystals (Samples 4 and 5).

The next bed (Sample 6) is characteristic biointramicrosparite to biointrasparite. Among the cements, drusy sparite dominates and, to a lesser degree, meniscus cement. Primary intragranular porosity ranges from $20 \%$ to $30 \%$, and fenestral porosity is around $5 \%$.

The bed where Sample 8 was taken is biointramicrosparite (grainstone to packstone). The allochems are

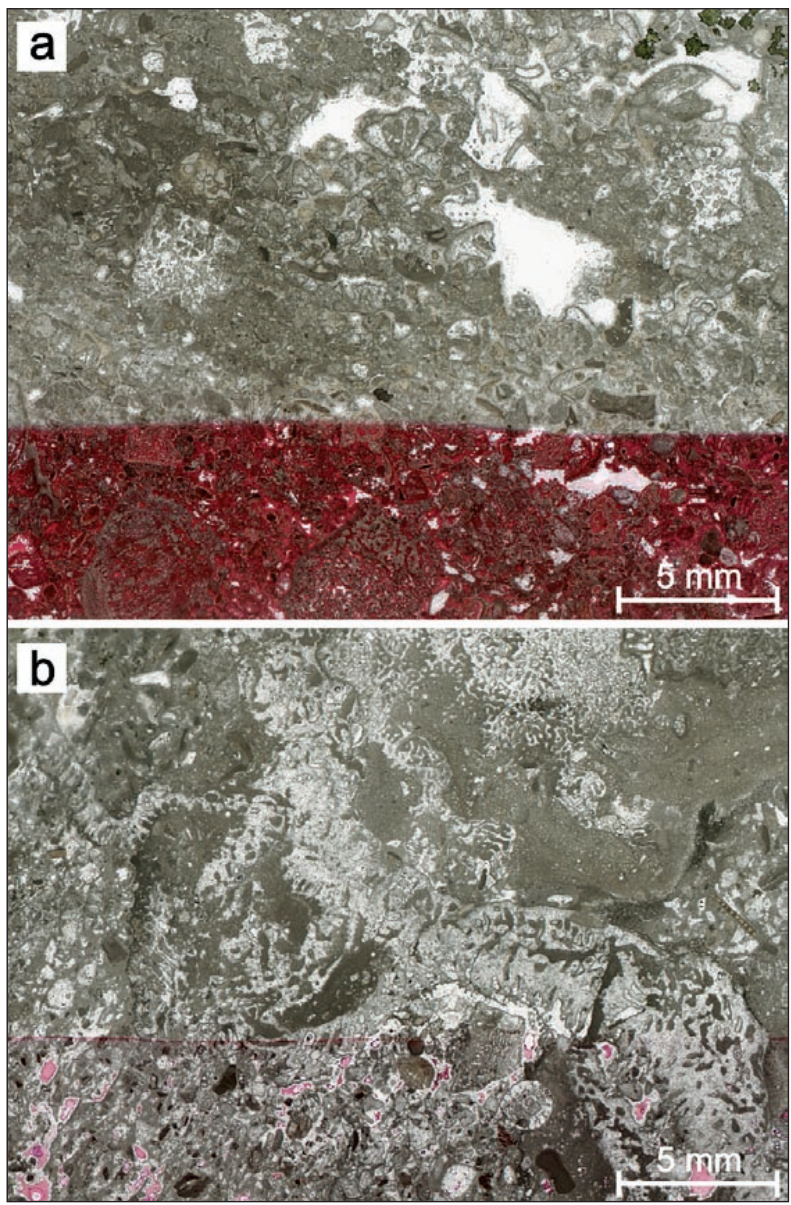

Fig. 6: Thin-sections of limestone section (a) and dolimitized section (b) of the profile.

calcitic, and the fenestrae are filled with dolomite crystals. Among orthochemical components, the sample contains micrite to microsparite cement that binds all the allochems very well. The larger surfaces between the orthochems are almost entirely occupied by euhedral crystals of dolomite that fill the fenestrae partly or entirely with an idiotopic texture.

The beds before the dolomitized series that forms the cliff are composed of biointrasparite to microsparite (grainstone) (Samples 9 and 10). Fragments of fossils dominate among the allochems, and the cement is largely meniscus and fibrous microsparite and anhedral to subhedral dolomite crystals forming a xenotopic to hypidiotopic texture between the allochems. The intragranular porosity in the beds changes laterally and is estimated to be between $10 \%$ and $40 \%$.

\section{Dolomitized cliff area}

The bed where Sample 11 was taken lies at the foot of the cliff and is composed of biointramicrosparite to biointrasparite dolomite (bafflestone to framestone). 
The transition between limestone and dolomite or between the limestone bed (Sample 10) and the dolomite bed (Sample 11) is sharp. In terms of minerals, dolomite dominates (Tab. 1) while the rest is calcite filling individual fenestrae that are 0.15 to $0.45 \mathrm{~mm}$ in diameter. Most of the fossils in the bed are corals in situ and their numerous fragments with some ostracod plankton and uniserial and biserial foraminifera as well. The cement is composed of unimodal dolomite euhedral to subhedral crystals and occasional anhedral crystals. The porosity is primarily intragranular to fenestral and partly framework porosity and is estimated at less than $5 \%$.

The next bed is composed of biointramicrosparite dolomite (bafflestone to framestone) (Sample 12) with numerous plankton and other foraminifera. The porosity in this bed is slightly higher, from $10 \%$ to $15 \%$.

The bed where Sample 15 was taken is biointramicrite (grainstone to framestone). This is a limestone bed inside the dolomite sequence that contains less than $1 \%$ dolomite. Dolomite crystals occur only at the edges of fenestrae. Individual smaller fenestrae are completely filled with dolomite crystals. The porosity is almost entirely fenestral.

Above the limestone bed the rock transitions immediately into dolomite again with no gradual changes (Sample 16). The dolomite is biointramicrosparite to biointramicrite (packstone to grainstone). Coral fragments, plankton foraminifera, and individual gastropods dominate among the fossil remains. The cement filling the gaps between clasts and individual fenestrae is euhedral dolomite.

The bed where Sample 18 was taken stands out for its content of insoluble residue, which totals a good $13 \%$. Slightly micritized fragments of mostly unidentifiable fossil remains dominate the sample; intraclasts comprise less than $1 \%$. The areas between the intraclasts and the numerous fenestrae are filled by mostly euhedral to subhedral crystals of dolomite. The porosity is distinctly fenestral and is estimated at $10 \%$ to $15 \%$.

The rock in the beds where samples 19, 20, and 21 were taken is biointramicrosparite to biointrasparite (bafflestone to framestone). The cement between clasts is euhedral drusy dolomite cement. Individual fenestrae are filled with subhedral dolomite crystals. The primary porosity is intragranular with additional fenestral and framework porosity.

The top of the studied profile (Samples 22 and 23) is biointramicrite (packstone with transitions to bafflestone and framestone). Among the fossil remains, corals and their fragments dominate, and the cement is drusy mosaic cement that forms a xenotopic texture. Along the inner edges of fenestrae there are euhedral crystals of dolomite. Fenestral porosity dominates. The porosity totals $5 \%-10 \%$ and varies laterally.

\section{South port}

The rock (Samples 27 and 27a) in the southern port (Fig. 1 , point 2) is biointramicrosparite limestone (grainstone to packstone), which differs from the Ohde and Kitano observations (1982). It contains $65 \%$ to $70 \%$ calcite. The cement is mostly carbonate micrite; the fenestrae are filled with drusy mosaic dolomite.

\section{West port}

The rock (Sample 28) in the western port (Figs. 1 (point 3 ), 4D) is biointrapelmicrosparite limestone (packstone to grainstone). Mineral calcite (more than $80 \%$, Tab. 1) dominates in the rock, and fragments of fossils, corals, bivalves, gastropods, and numerous plankton foraminifera dominate distinctly among the allochems. In several phases, the fenestrae are radially filled with alternating calcite and dolomite crystals. The porosity is mostly fenestral and totals a few percent.

\section{North port}

The rock in the northern port is biointramicrosparite dolomite (packstone to grainstone and bafflestone) (Sample 26, Fig. 1, point 4). The allochems are cemented by drusy mosaic dolomite euhedral to subhedral crystals that form extensive areas of idiotopic texture. The porosity is primarily intragranular and estimated at $5 \%$.

\section{Cave Point 7}

The rock above Cave Point 7 (Fig. 1, point 5) is biointrasparite dolomite (mostly grainstone) (Tab. 1, Sample 37). The cement is drusy mosaic euhedral dolomite forming large areas of idiotopic texture. Euhedral dolomite crystals grow along the inner edges of fenestrae. Primary fenestral and partly intragranular porosity totals around $20 \%$. Samples 38 to 41 are stalagmite samples.

\section{Oshiro 1 Cave}

The sample above the cave (Fig. 1, point 6) is pelmicrite dolomite (mudstone) (Samples 33, 34, and 35). Dolomite dominates heavily among the minerals in the sample, and fossil remains total less than $0.5 \%$. Euhedral dolomite crystals, mostly belonging to one generation, grow on the inner edges of the fenestrae. The porosity is fenestral and totals $10 \%$ to $20 \%$. The sample of stalagmite (Sample 36) from Cave 2 is almost $90 \%$ calcite.

\section{Oshiro 2 Cave}

The rock above the cave (Fig. 1, point 7) is biointrapelmicrite limestone (packstone) (Sample 30, Tab. 1). It contains numerous fragments of corals, bivalves, fragments and unbroken examples of large foraminifera and plankton foraminifera, tiny gastropods, and fragments of Echinodermata. The cement is micrite calcite, and there is drusy mosaic calcite on the inner edges of fenestrae and some fossils. The central parts of the fenestrae are mostly filled with euhedral to subhedral dolomite crystals. The pri- 
mary intragranular and fenestral porosity is estimated at less than $1 \%$. Samples 31 and 32 are cross sections of a stalagmite composed of more than $90 \%$ calcite.

\section{Hoshinodo Cave}

Two rock samples were taken from the cave: the first sample (Sample 24, Fig. 1, point 8) is biointrasparite to biointramicrite dolomite (grainstone). Intraclasts comprise up to $5 \%$, the cement is drusy mosaic dolomite cement, and only individual fenestrae are filled with calcite. Sample 25, taken in the immediate vicinity of Sample 24, is biointramicrosparite dolomitic limestone (packstone to grainstone). The cement between clasts is mostly calcite drusy mosaic cement, and inside allochems mostly drusy mosaic dolomite cement. The primary porosity is intragranular and fenestral and ranges from $5 \%$ to $15 \%$.

\section{ROCK RELIEF OF KARST SURFACE}

The karren is divided into that found in the interior of the island that developed from subsoil karren into karren shaped by rain and coastal karren. In the interior of the island, rain has reshaped denuded karren, while the outer edge of the ridge is dominated by traces of corrosion and erosion activity.

\section{Interior karren}

Denuded karren are rock masses up to $10 \mathrm{~m}^{2}$ in size that reach two meters in height. The karren is especially distinct on the higher rocky ridge that encircles the island. The central part of the island is mostly covered by soil with only smaller protruding rock surfaces.

On the rocky ridge, the karren first develops under the soil (Slabe \& Knez 2004) and is reshaped after denudation. Longitudinal subsoil notches formed at the level of the soil that surrounded the rock for a longer period. They are dissected by subsoil cups that reflect the porosity of coral rock. Subsoil tubes often form and hollow the rock in three dimensions. Some are paragenetically reshaped. The largest subsoil caverns, which can be one meter in diameter, are found along bedding contacts. The subsoil corrosion of porous rock is distinct and the larger karren forms often have mushroom shapes.

Half bells up to one meter in diameter are found below the funnel-like notches that dissect the tops of karren. They form due to the consolidated flow of water to the soil and its spreading laterally along the contact. Large subsoil channels with diameters that reach one meter are only found on the walls of cracks up to several meters in width and several tens of meters in length that cross the ridge. The tops of the rocks are distinctly dissected into numerous peaks and ridges. They form within a dense network of subsoil cups with occasional subsoil channels between them. The cups and channels form below the soil that still covers the rock in places. In most cases, the subsoil rock forms are relatively deep and their walls distinctly dissected due to the composition of the porous rock.
Relatively dense root systems are often found in subsoil caverns. They stretch all the way to the caves because the subsoil caverns contain soil. Smaller plants grow also from the caverns onto the denuded rock. Recently denuded smaller rocks shaped exclusively by subsoil processes are found in the central part of the island.

As a rule, subsoil rock forms on coral rock are smaller than average due to the high porosity of the rock and the three-dimensional spreading of water at the contact of rock and soil and in caverns. Subsoil-shaped rocks have relatively round and smooth shapes.

Denuded subsoil recesses whose bottoms do not continue into hollows are reshaped into solution pans. The composition of coral rock does not enable the formation of rain flutes. The surface of the rock is rough. Scallops, the trace of creeping water, grow on overhanging sections. Rainwater flows through tubes, reshaping them and simultaneously shaping the rock at their other end where recesses similar to solution pans are found at the mouths and channels are found under the mouths.

\section{Coastal karren}

The karren (Fig. 4) that stretches to the top of the ridge encircling the island can be divided into that within direct reach of seawater and that shaped by various amounts of sea spray and rain. The former are shaped by seawater most of the time or just periodically by high waters or large waves.

The diverse and most characteristic types of coastal karren have been clearly described and explained by Lundberg (2009) and Lace and Mylroie (2013).

This study is focused primarily on the specific features in the formation of the coast in the unique environment of Minamidaito Island.

There is a rock shelf at sea level that in places is several tens of meters wide. It is either completely submerged or only along its outer section and usually slopes gradually upward toward the island. It is flooded by high 


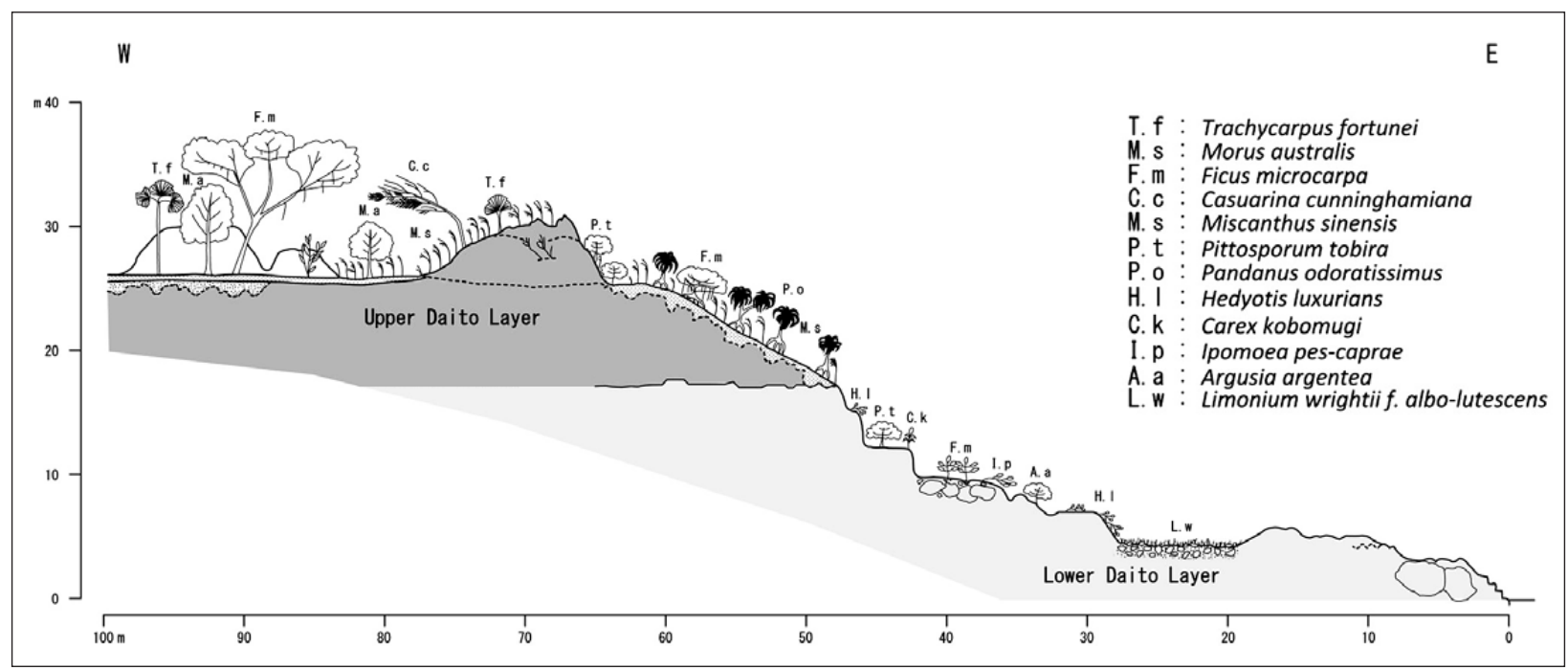

Fig. 7: Cross-section of the coast with vegetation.

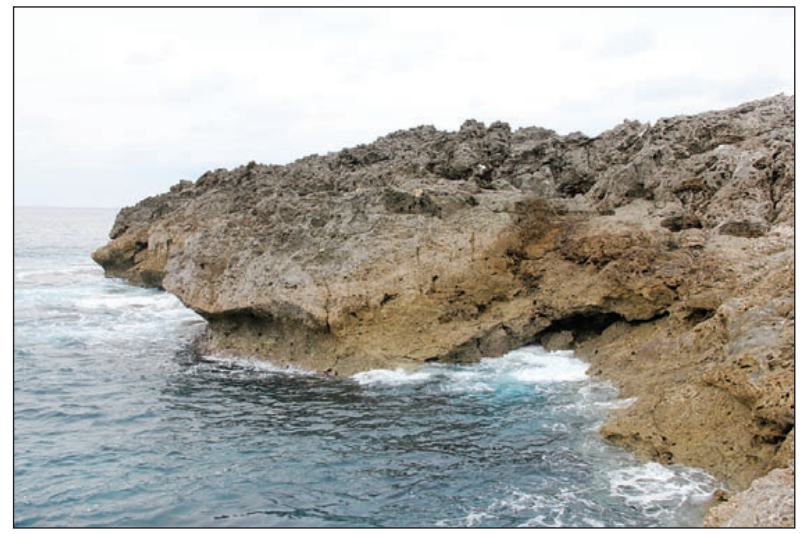

Fig. 8: Sea notch.

waves that carve notches where they touch the wall. A vertical wall up to ten meters high typically rises above the shelf and ends in a steep rim. Above this is another rock shelf, tens of meters in width, ending in another steep wall (Figs. 5, 7). This is repeated one more time but less distinctly before the top of the ridge. The surfaces of the first two ledges are bare but the topmost ledge is overgrown.

In the area of direct sea action, the shape of the edge of the island dictates the rock relief. Longitudinal sea notches (Figs. $4 \mathrm{~A} 1,8$ ) several meters in diameter are most distinct in parts where the shelf surrounding the island is the narrowest and the cliff above it is steep and more or less high. Shelves washed by the sea are found at various heights; wall notches form above those located at the lowest level while steep walls are found above higher-lying shelves. The notches are deeper at distinct fissures. Their upper parts overhang distinctly and their circumferences are often dissect- ed by half-pockets dictated by the inner currents of waves or the shape of the coast. There are small sea pans on the lower more gently sloping parts of the notches, often arranged in a longitudinal series. This series arrangement also applies to large pans on the ledges above the notches at levels most often reached by high waves and below steep walls above shelves where there are no longitudinal notches (Figs. 4 A3, 8 ). Higher sections of karren are shaped by sea spray; if high waves do not reach them very often they are quite distinctly dissected by numerous small pinnacles (Figs. 4 A4, 8).

Sea pans (Fig. 4) are one of the most frequent and characteristic rock forms among the coastal karren on Minamidaito Island. These are depressions with diameters that range from one centimeter to several meters. Their diversity reveals the manner of their formation in different areas of coastal karren and their position on variously inclined rock surfaces.

Large pans have diverse origins. Sea pans linked to notches have characteristic positions. Pans found on the edge of the shelf at the level of the sea are completely submerged during high tide and retain seawater at low tide. Higher on the shelf where the dissected surface of karren lies several meters above sea level, they are within reach of high waves and farther up they are found where the most distinct spray of seawater occurs. The densest network of pans is found on the shore platform at sea level (Figs. 4 B6, 9).

Seawater shapes these pans through corrosion when it completely or partly fills them and through erosion by wave action or the swirling of sand and pebbles. Higher up, the pans (Fig. 4 C8) are shaped by a combination of sea spray and rainwater and biocorrosion becomes a sig- 


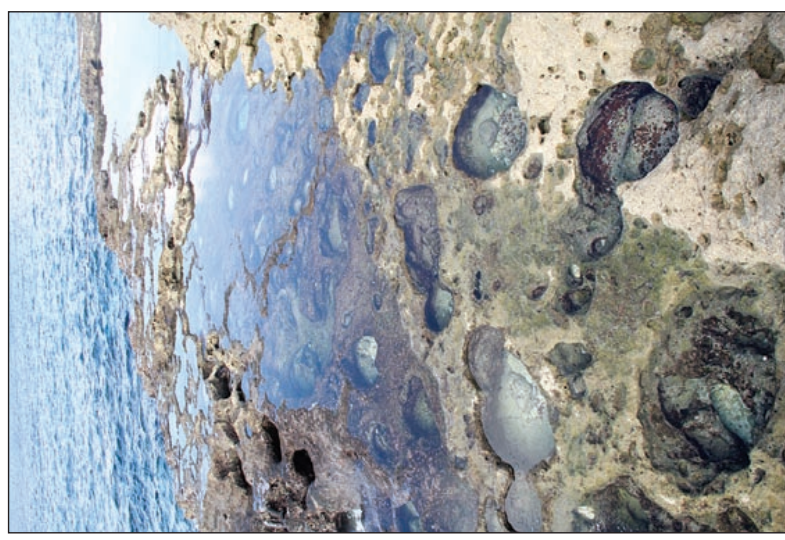

Fig. 9: Sea pans.

nificant factor. The pans are frequently open at the inflow side of the waves (Fig. 4 B7). Initial periods of their formation are visible in the small and dissected pans carved relatively deeply in the rock. Smaller pans form in the bottoms of larger and already open pans. In areas of the most distinct erosion action of the sea with sand and pebbles, the pans are largely shaped by erosion and could also be called potholes (Fig. 4 A5, D5). Their walls are erosion-polished and their bottoms are covered by sand and pebbles. The degree of interweaving of the corrosion and erosion actions of seawater varies. Only the bottoms of pans periodically exposed to seawater, especially during typhoons, are reshaped by sand, and the larger ones also by pebbles. Traces of sea spray action dominate their dissected edges.

The entire surface of the shelf at sea level is dissected with larger depressions, five meters or more in width, containing pans filled with pebbles and sand (Figs. 4 B6, 9). The larger depressions developed from older connected pans. In places they are separated by distinct meandering ridges. The entire bottoms of pans are shaped by erosion or their bottoms are dissected by smaller potholes. The surface between them is rounded and smooth. This is a process of the pans gradually lowering the shelf.

Due to corrosion and erosion, large channels with pans form along fissures running perpendicular to the shore (Fig. 4 D4).

The smallest pans (Figs. 4 A2, C2, D2, E2), between one centimeter and one or two decimeters in size, are located on inclined surfaces within reach of tides and waves. They often cover the entire surface of the rock and are found closely side by side or joined. They are often open on the water side. In places, especially on steeper sections, they develop into a network of small hollows. Water from the waves constantly flowing off the rock has an erosive effect as well, removing protruding parts, especially at the edges of pans. The manner of their shaping is also dictated by the composition of the rock. Higher

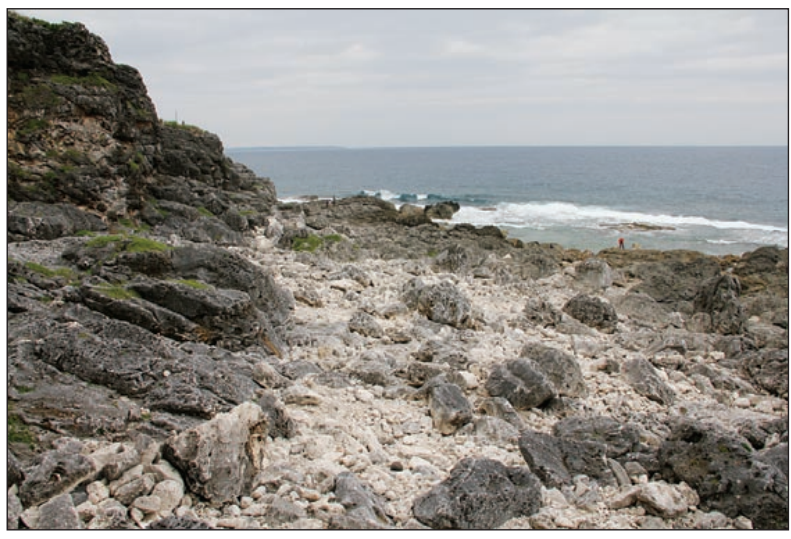

Fig. 10: Traces of the erosion action of the sea water.

above this belt, the rock is overgrown by algae and lichen and covered by biocrusts. The smallest pans are therefore located in the area of constant tides and waves.

Pans (Figs. 4 B8, C8) located on the shelf just a few meters above the sea formed primarily by sprayed seawater and rain occur individually in most cases. The surface between them is polished by the periodic erosive action of waves or dissected by spray.

In addition to seawater corrosion and erosion, biocorrosion plays an important role in the process of shaping coastal karren. The composition of the rock also influences its shaping to a considerable extent.

It is possible to describe generally the most characteristic cross sections of coastal karren. The width of shore platforms at sea level varies. They are usually dissected by pans that are often co-shaped by corrosion. The steep cliffs along the coast, especially those behind narrower shore platforms, have distinct longitudinal notches (Fig. $4 \mathrm{~A} 1$ ). On the tops above them, the rock is heavily dissected by pinnacles and solution pans due to seawater spray (Fig. 4 A4). The lower section of the gradually rising erosional ramp is relatively smooth. In the area of constant wave activity, the rock is dissected by smaller solution pans and below the cliff it is dissected by larger ones, as a rule arranged in a longitudinal series (Fig. 4 E2). The higher parts lying five to ten meters above sea level are dissected by the relatively distinct seawater spray that is the dominant factor. These parts of the shelf are only occasionally flooded. However, the power and impact of the floods is huge, especially during the long-lasting activity of typhoons when the wind reaches speeds as high as $280 \mathrm{~km} / \mathrm{h}$. These parts also have erosion-polished rock surfaces and combined rock forms (Fig. $4 \mathrm{D}$ ). These features are most distinct in lower, especially crosswise notches. Larger belts are covered by sand, pebbles, and boulders whose diameter on exposed positions can exceed one meter. Higher-lying surfaces are dissected primarily by seawater spray and are 


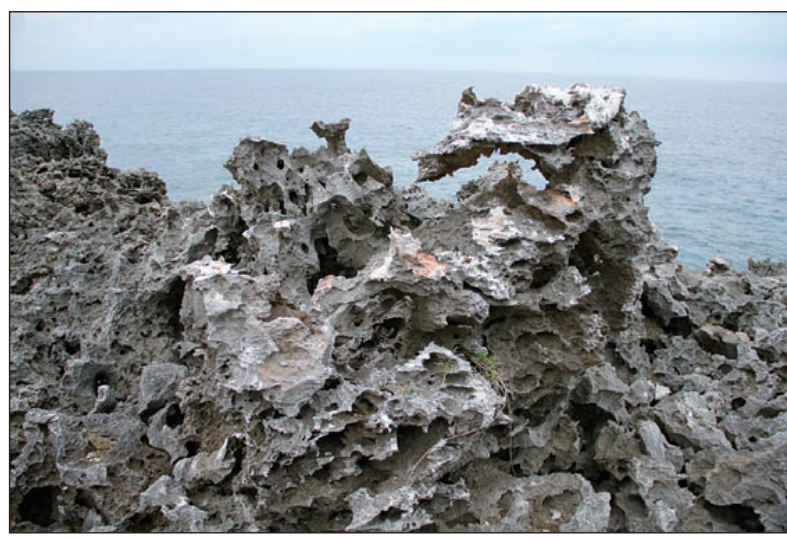

Fig. 11: Rock etched by the sea spray.

often covered in lichen. The immense erosive power of the sea in earlier periods is also demonstrated by the erosion caves (Figs. 4 D9, 10) in the cliffs above old shelves located five and more meters above the current water level. They can be several meters in length and their circumferences are polished by erosion.

Higher up the ridge on the top platform, the rock is thickly overgrown (Figs. 4, 5, 6). Subsoil recesses (Fig. 4 D10) in the coral rock are filled with soil and crisscrossed by roots. The previously described rock forms are found below the soil, and the rock is rounded and relatively smooth. Often soil is only found deeper in the pockets, and there are plants growing on the surface of the rock in their upper parts. The surface layer of bare rock is distinctly perforated and dissected according to its composition (Figs. 4 E11, 11).

The coral rock is most distinctly dissected on steep parts of the slope at the top of the ridge that are mostly denuded. There are often more hollow areas than areas of solid rock since the rock has disintegrated to become scree at the foot of the cliffs. The rock is shaped by the seawater spray and rainwater that washed away the soil and exposed the subsoil-dissected rock.

\section{Rock relief of large crevice}

Special rock relief dissects the wall of a large horizontal crevice in the outer edge of the island (Fig. 1, point 9). The crevice is up to 20 meters deep and up to 5 meters wide. Rock forms that developed at the contact with sediment and that are the traces of water creeping down the rock dominate the rock relief. The former are primarily large subsoil channels, scallops, and pockets. These forms developed due to water creeping along the contact with the sediment that filled the crevice. Longitudinal wall notches and half-bells formed at the level of the sediment or just below it.

More gently sloping sections of rock are dissected by a dense network of subsoil cups that developed below

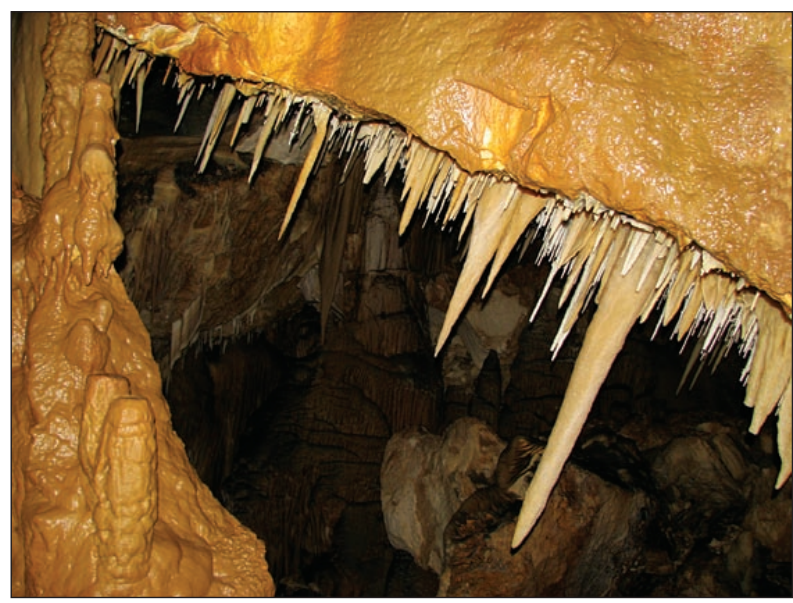

Fig. 12: Collapsed ceiling in the Hoshinodo cave.

the weathered debris that covers the rock in places. Often they overgrow into a three-dimensional network of hollows as a result of the composition and great porosity of the rock. The roots of the dense vegetation grow through the rock.

Due to the trickling of water, less distinct small channels formed on the walls in places. The smaller protrusions that formed between surfaces where the water trickles are more distinct. These are up to 3 centimeters wide and up to 10 centimeters high and end in a point.

\section{Rock relief of caves}

The majority of the accessible rock relief in the relatively numerous karst caves are traces of the decomposition of a rock layer. The upper part of the circumference of passages is therefore angular in most cases and the floor is covered with rock fragments. This indicates the relatively great instability of such circumferences in coral rock, especially in larger cave spaces (Fig. 12).

Ceiling pockets are found only on individual parts of the circumference of passages that have been preserved for longer periods. They are often composite in character or sometimes smaller ceiling pockets dissect larger ones. The dissected surface indicates that they were not formed by distinct eddies. Some ceiling pockets, particularly those with bell-like extentions, have an inflow tube at the top, which indicates they could have been co-shaped by percolating water.

Preserved rock forms that developed at the contact with the fine-grained sediment that filled especially the lower parts of caves that were often flooded are relatively rare. Above sediment that entirely filled passages, water percolating through the porous ceiling formed ceiling pockets. On rock floor at the water table level, sub-sediment cups and sub-sediment flutes developed in places due to the percolation of water from fine-grained sediment. 
The rock relief of caves primarily reveals the fragility of the rock circumferences and the porosity of the rock.

\section{Formation of rock relief on coral rock}

The majority of the most important factors in the formation of karst surfaces and caves are clearly visible in the rock relief. The impact of the coral composition of the rock with larger component parts on the formation of the karst relief is relatively distinct.

The subsoil surface is rounded and smooth and often densely perforated between component parts. Subsoil notches, large channels, and half-bells, the largest subsoil rock forms, develop. The composition of the rock mostly influences their surfaces. It emphatically determines the formation of rock forms that develop on rock partly covered by soil or weathered debris. Dissected subsoil cups start to take shape between larger component parts and grow into small cavities.

The composition of the rock has a more distinct impact on the development of rock forms shaped by rain- water. Since it is composed of mostly larger coral areas, the smallest rock forms such as rain flutes do not develop. Only larger rain channels and very dissected solution pans can form here. Denuded rock dissects distinctly into increasingly less connected composite forms that disintegrate over time.

The influence of the composition of the rock is least distinct on the forms shaped by seawater through erosion and mechanically by gravel and sand. Surfaces of large coastal potholes and the walls of coastal predominantly erosion caves are rounded by erosion and the surface is somewhat evenly ridged. The circumferences of predominantly corrosion and biocorrosion coastal solution pockets and larger solution pans flooded by seawater are relatively smooth as well. The composition of the rock is more distinctly reflected on surfaces reached only by the spray of seawater and rain. These are dissected and often co-shaped by biocorrosion.

In the future, it will be necessary to identify the characteristics of the formation of coral limestone and dolomitized limestone in greater detail.

\section{KARSTIFICATION PROCESSES ON MINAMIDAITO ISLAND}

\section{(1) The Pliocene}

During the Pliocene, Minamidaito Island was located in an uplifted zone of the Philippine plate, as was Kitadaito Island. On both islands, the unconformity between the lower Daito Layer (dated as about 5-4 Ma) and the upper Daito Layer (dated as about $2 \mathrm{Ma}$ ) is clearly evident. In particular, the unconformity layer appears as a layer of fossil soil 10-20 centimeters thick on Minamidaito Island (Figs. 3, 5, 6) and is proof of a long period of karstification. The time required for the soil formation process can be estimated as at least 100 to $200 \mathrm{ka}$. The reason for this estimate, as given by Nambu et al. (2003), is the lowering of seawater in a cooler period of climatic change. These soil layers can be observed along the northwest coast of Minamidaito Island. On the east coast of the island, the unconformity layer without soil cover can be observed at an elevation of about 20 meters a.s.l. (Fig. 3).

\section{(2) The Pleistocene}

The shape of Minamidaito Island makes it look like an atoll. However, according to its geology and karst features, it is estimated that the island has been karstified for a long period. Because the upland profile with two to four lines of rock walls with thin soil layers has an average elevation 40 to 50 meters a. s. l. with bottom basin 2 to $8 \mathrm{~m}$ a.s.l. The difference elevation of the top limestone walls and the basin is too large for a present atoll. There- fore, it should be the results of karstification. Flint et al. (1959) described the rock walls as the residual terrain of solution processes. At first, limestone tablets taken from the upper Daito Layer were used in a study. The karstification of these tablets was measured for twelve years under the present climate condition on Minamidato Island (Urushibara-Yoshino et al. 2009). The results were applied to calculating the period of karstification at about 1.6 Ma and less than 1.7 Ma (Urushibara-Yoshino 2009; Urushibara-Yoshino et al. 2009, 2017). These results fit very well with the figure for the dolomitized age of Unit 1, 1.6 Ma, that had been obtained in previous studies.

\section{(3) Karst terrains on the eastern}

\section{Kaigunbo coast}

At the end of the Pleistocene and during the Holocene, typical karst terrains developed in the coastal areas of the island. The east coast profile with pinnacles and soil development with vegetation (Figs. 3, 5, 6). The vegetation processes have progressed from grasses to trees according to the location of the karst terrain. In the inland part of the outermost rock ridge, soils and vegetation have developed ecologically very well. In contrast, denuded pinnacles and depressions have developed very well on the outer side of the rock ridge. Conglomerates which cover Lower Daito layers might form during climatic optimum when sea level was slightly higher than present one. 


\section{CONCLUSION}

There were three karstification periods on Minamidaito Island. The first karstification occurred during the Pliocene between the lower and the upper Daito Layer. The top surface of the lower Daito Layer was karstified and soils formed. During the Pleistocene, karstification continued from 1.6 Ma until the last glacial period. The terrain of Minamidaito Island, which resembles an uplifted atoll, continued to karstify until the middle of the last glacial period when the sea level dropped by 100 meters. Since then karstification similar as today is taking place. The borehole data collected by Sugiyama $(1934,38)$ proves this. During the Holocene, the sea level rose.

The geological studies were also augmented with results of studies from the Kitadaito atoll located 12 kilometers to the northeast (Suzuki et al. 2006). Their proximity and locations make it reasonable to believe that the two islands share very similar or even identical formation and development processes. Numerous rock samples from different parts of Minamidaito Island were studied in detail and subjected to calcimetric analyses. Coral biointrasparite limestone (framestone and bafflestone with transitions to grainstone) and coral dolomitized biointrasparite limestone (framestone and bafflestone) with around $75 \%$ dolomite in the total carbonate content were identified. The complexometric analyses showed that the distribution of limestone and dolomite in individual locations differed from that previously described (Ohde \& Kitano 1982). The rock transitions from limestone to dolomite in areas out of reach of even the highest waters but under constant impact of seawater spray. The line between the limestone lying below and the dolomite lying above probably corresponds to the line between the Lower and Upper Daito formations that formed in the Pliocene. Unlike Kitadaito Island where the majority of calcitic dolomites (Suzuki et al. 2006) were found in coastal sites, it was established that a large proportion of the southern coastal sites on Minamidaito Island are probably composed of limestone and the higher elevations of dolomite. There are different models of dolomiti- zation. Suzuki et al. (2006) believe that the dolomite on nearby Kitadaito Island formed through seawater dolomitization during the glacial lower sea level, which is the most frequent explanation for dolomitization on atolls. We assume that Minamidaito Island experienced similar geological and environmental conditions. The described carbonates are a typical example of carbonate sediments of a shallow coastal belt; therefore, the sedimentation environment of the profile near Kaigunbo and other areas are ranked as the area of reef environment.

Although the characterisitics of coral limestone and dolomitized limestone put a distinctive stamp on the rock relief, it remains an important trace of the formation and development of this unique karst landscape. The rock is often heavily perforated in three dimensions during the subsoil phase, when the subsoil formation is followed by denudation, and ultimately when it suffers corrosion due to rain and seawater spray. The rocky circumference of caves is subject to decomposition. The coral composition of the rock is distinctly reflected in rock relief forms as well. The rock is relatively smooth only in places hollowed by the erosive and corrosive action of waves and subsoil processes; rock exposed only to rain is less dissected than that exposed to seawater spray as well. The unique features of the rocky shoreline are dictated by the erosive power of the sea, especially during periodic typhoons. This periodic character is evident in the dominant proportion of features created by the corrosive activities of seawater, biocorrosion, and biocrust and the state of erosion forms found several meters inland, on shore platforms, or in walls. The surface of the interior of the island was formed under the soil; only the denuded sections of karren are transformed by rain. The rock relief of caves reveals their formation in the phreatic zone and the more or less distinct oscillation of the water level in them, the filling of passages by finegrained sediment and the deposit of smaller quantities of fine-grained sediment on the circumference, and the distinctly porous rock of the ceiling and the heightening of passages due to its decomposition.

\section{AKNOWLEDGEMENTS}

This study was supported by grant-in-aid for Scientific Research Program, Ministry of Education, Science, Sports and Culture, Japan (Project number, 23501250, under the leadership of Kazuko Urushibara-Yoshino), 2012. The authors acknowledge the financial support from the
Slovenian Research Agency (research core founding No. P6-0119) and Unesco IGCP project no. 598 and EU project in the FP7: LIFEWATCH - E-Science European Infrastructure for Biodiversity and Ecosystem Research. 


\section{REFERENCES}

Al Farraj Al Ketbi, A., Slabe, T., Knez, M., Gabrovšek, F., Mulec, J., Petrič, M. \& N. Zupan Hajna, 2014: Karst in Ras Al-Khaimah, northern United Arab Emirates.- Acta Carsologica, 43, 1, 23-41. DOI: https:// doi.org/10.3986/ac.v43i1.579

Debevec, B., Knez, M., Kranjc, A., Pahor, M., Prelovšek, M., Semeja, A. \& T. Slabe, 2012: Preliminary study for the adaptation of the "Heaven's Cave" for tourist purposes (Phong Nha-Ke Bang National Park, Vietnam).- Acta Carsologica, 41, 1, 115-127. DOI: https://doi.org/10.1016/j.tmp.2015.10.004

Dunham, R.J., 1962: Classification of carbonate rocks according to depositional texture.- In: Ham, W.E. (ed.) Classification of Carbonate Rocks. Am. Ass. Petrol. Geol., 1, 108-121, Tulsa.

Embry, A.F. \& J.E. Klovan, 1972: Absolute water depth limits of Late devonian paleoecologic zones.Geol. Rundschau, 61, 672-686. DOI: https://doi. org/10.1007/bf01896340

Engelhardt, W., Füchtbauer, H. \& G. Müller, 1964: Sediment-Petrologie, Methoden der SedimentUntersuchung, Teil 1.- E. Schweizerbart'sche Verlagsbuchhandlung (Nägele u. Obermiller), pp. 303, Stuttgart.

Flint, D. E., Saplis, R. A. \& G. Crowin, 1959: Military geology of Okinawa-jima, Ryukyuretto (5).- Geol. Surv. Branch, Intell. Div. Office Eng. Hg. U. S. Army Forces, Far East, Personal of U.S. G.S.

Folk, R.L., 1959: Practical petrographic classification of limestones.- Am. Ass. Petrol. Geol. Bull., 43, 1-38.

Folk, R.L., 1962: Spectral subdivision of limestones types. In: W. E. Ham (ed) Classification of carbonate rocks.- Am. Ass. Petrol. Geol., 1: 62-84, Tulsa.

Gutiérrez Domech, R., Knez, M. \& T. Slabe, 2015: Felo Pérez Mogote (Viñales, Pinar del Río, Cuba): typical shaping of rock surface below dense tropical vegetation.- Acta Carsologica, 44, 1, 47-57. DOI: https:// doi.org/10.3986/ac.v44i1.680

Ginés, A., Knez, M., Slabe, T. \& W. Dreybrodt, 2009: Karst rock features: karren sculpturing.- Carsologica 9, ZRC Publishing, pp. 561, Ljubljana.

Hanzawa, S., 1940: Micropaleontological studies of drill cores from a deep well in Kita-Daito Zima (North Borodino Island).- Jubil. Publ. Comm, Prof. H. Yabe Sixtieth Birthday, 2, 755-802.

Hideo, T., Nakayama, Y., Ishikawa, T., Nagaishi, K. \& Y. Iryu, 2010: Sr isotope composion of island-surface dolomite at Kita-daito-jima, northern Philippine Sea.- Jour. Geol. Soc. Japan, 116, 4, 237-240. DOI: https://doi.org/10.5575/geosoc.116.237
Inagaki, S. \& Y. Iryu, 1998: Sedimentology and oxygen and carbon isotope stratigraphy for Kita-daito-jima Bore Hole.- $15^{\text {th }}$ Int. Sed. Congr., Abstracts, 441, Alicante, Spain.

Knez, M., Rubinić, J., Slabe, T. \& E. Šegina, 2015: Karren of the Kamenjak hum (Dalmatian Karst, Croatia): from the initial dissection of flat surfaces by rain to rocky points.- Acta Carsologica, 44, 2, 191-204. DOI: https://doi.org/10.3986/ac.v44i2.1546

Knez, M., Liu, H. \& T. Slabe, 2012: Major stone forest, litomorphogenesis and development of typical shilin (Yunnan, China).- Acta Carsologica, 41, 2/3, 205218. DOI: https://doi.org/10.3986/ac.v41i2-3.558

Knez, M. \& T. Slabe, 2002: Unroofed caves are an important feature of karst surfaces: examples from the classical karst.- Zeitschrift für Geomorphologie, 46, 2, 181-191.

Knez, M., Slabe, T. \& L.E. Panisset Travassos, 2011: Karren on laminar calcarenitic rock of Lagoa Santa (Minas Gerais, Brazil).- Acta Carsologica, 40, 2, 357-367. DOI: https://doi.org/10.3986/ac.v40i2.19

Knez, M., Slabe, T. \& K. Urushibara-Yoshino, 2013: New researches at coral Minamidaito Island (Nansei Archipelago, Southeast Japan).- Memorias de Geociencias, Havana, 1040-1048.

Lace, J.L. \& J.E. Mylroie (eds.), 2013: Coastal Karst Landforms.- Springer, pp. 429. DOI: https://doi. org/10.1007/978-94-007-5016-6

Lundberg, J., 2009: Coastal karren.- In: Ginés, A. et al. (eds) Karst Rock Features: Karren Sculpturing.ZRC Publishing, pp. 249-264, Ljubljana.

Nambu, A., Inagaki, S., Ozawa, S., Suzuki, Y. \& Y. Iryu, 2003: Stratigraphy of reef deposits on Kita-daito-jima, Japan.- Jour. Geol. Soc. Japan, 109, 11, 617-634. DOI: https://doi.org/10.5575/geosoc.109.617

Ohde, S., 1987: Geochemistry of Sedimentary Protodolomite.- The Journal of Earth Sciences, Nagoya University, 35, 2, 167-180.

Ohde, S. \& H. Elderfield, 1992: Strontium isotope stratigraphy of Kita-daito-jima Atoll, North Philippine Sea: implications for Neogene sea-level change and tectonic history.- Journal of Geography, 113, 473-486. DOI: https://doi.org/10.1016/0012-821$\mathrm{x}(92) 90125-\mathrm{f}$

Ohde, S. \& Y. Kitano, 1982: Distribution of Protodolomite in Minami-daito-jima, Okinawa.- Bulletin of the College of Science, University of the Ryukyus, 33, 81-87. 
Ota, Y., Omura, A., Koba, M., Kawana T. \& T. Miyauchi, 1991: Late Quaternary Tectonic Movements as Deduced from Raised Coral Reefs of Daito Islands on the Northwestern Part of Philippine Sea Plate.- Journal of Geography, 100, 3, 317-336. DOI: https://doi. org/10.5026/jgeography.100.3_317

Omura, A. \& Y. Ota, 1992: Paleo sea-level change during the last 300,000 years deduced from the morpho-stratigraphy of coral reef Terraces and 230 Th/ 234U Ages of Terrace Deposits.- The Quaternary Research, 31, 5, 313-327.

Slabe, T., Hada, A. \& M. Knez, 2016: Laboratory modeling of karst phenomena and their rock relief on plaster, subsoil karren, rain flutes karren and caves.Acta Carsologica, 45, 2, 187-204. DOI: https://doi. org/10.3986/ac.v45i2.4623

Slabe, T., 2005: Two experimental modelings of karst rock relief in plaster: subcutaneous "rock teeth" and »rock peacks« exposed to rain.- Z. Geomorph. N. F., 49, 107-119.

Slabe, T., 2009: Karren simulation with plaster models.In: Ginés, A. et al. (eds), Karst Rock Features: Karren Sculpturing.- ZRC Publishing, pp. 47-54, Ljubljana.

Slabe, T. \& M. Knez, 2004: Kraške podtalne skalne oblike [engl. summary: Karst Subsoil rock forms].- Ann., Ser. hist. nat.14, 2, 259-266.

Sugiyama, T., 1934: Concerning the borehole date in Kitadaito Island, Contributions from the Institute of Geology and Paleontology.- Tohoku University, 11, 1-44. (in Japanese)

Sugiyama, T., 1936: Second report concerning the borehole date in Kitadaito Island, Contributions from the Institute of Geology and Paleontology.- Tohoku University, 25, 1-34. (in Japanese)
Suzuki, Y., Iryui, Y., Inagaki, S., Yamada, T., Aizawa, S. \& D. A. Budd, 2006: Origin of atoll dolomites distinguished by geochemistry and crystal chemistry: Kita-daito-jima, northern Philippine Sea.- Sedimentary Geology, 183, 181-202. DOI: https://doi. org/10.1016/j.sedgeo.2005.09.016

Toshio, K., Taira, H., Tanahara, A., Aoki, H., Ota, Y., Omura Y. \& M. Koba, 1991: ${ }^{226} \mathrm{Ra} /{ }^{238} \mathrm{U}$ dates by nondestructive $\gamma$-ray spectrometry of late pleistocene corals from Minami- and Kita-Daito islands, Okinawa, Japan.- Journal of Geography, 100, 3, 367-377. DOI: https://doi.org/10.5026/jgeography.100.3_367

Urushibara-Yoshino, K., 2003: Karst Terrain of raised coral island, Minamidaito and Kikai in the Nansei Islands of Japan.- Z. Geomorph., 131, 17-31.

Urushibara-Yoshino, K., 2009: Solution Rate of Limestone and Karst Terrain in Japan.- In: $7^{\text {th }}$ International Conference on Geomorphology.

Urushibara-Yoshino, K., Kashima, N., Enomoto, H., Haikawa, T., Higa, M., Tamashiro, Z., Sunagava, T. \& E. Ooshiro, 2009: Solution rates of limestone tablets and climatic conditions in Japan. In: Ginés, A. et al. (eds) Karst Rock Features: Karren Sculpturing.- ZRC Publishing, pp. 461-467, Ljubljana.

Urushibara-Yoshino, K., Lauritzen, S.E., Slabe, T., Knez, M., \& S. Oppata, 2017: Karstification processes of Minamidaito Island, in Japan's Nansei Islands.Transactions, Japanese Geomorphological Union, 34, 2, 107-128. 